\title{
Deficyt wsparcia społecznego - osoby niepełnosprawne w nieformalnych sieciach społecznych
}

\author{
Tomasz Masłyk \\ https://orcid.org/0000-0001-9901-5859 \\ AGH, Akademia Górniczo-Hutnicza w Krakowie
}




\section{Streszczenie}

Nieformalne sieci społeczne pod postacią kręgów rodzinnych, przyjacielskich czy koleżeńskich są źródłem wsparcia społecznego zapewniającego ochronę zasobów o charakterze emocjonalnym: zdrowia fizycznego, zdrowia psychicznego oraz zadowolenia z życia. Dla osób niepełnosprawnych dostęp do tych zasobów oraz możliwość ich mobilizacji pełnią szczególną rolę. Z jednej strony zasoby emocjonalne mogą kompensować braki w wymiarze instrumentalnym (statusowe), które nierzadko ze względu na niepełnosprawność pozostają poza zasięgiem osób nią dotkniętych. Z drugiej strony mogą pełnić rolę czynnika mobilizującego, zwiększającego szansę na podjęcie przez osoby niepełnosprawne działań zmierzających do pozyskania nowych zasobów. W tym kontekście podjęta została próba nakreślenia empirycznej ilustracji obrazującej: 1) naturę nieformalnych sieci społecznych osób niepełnosprawnych w Polsce (w wymiarze afektywnym i współzależności), 2) przedstawienia charakteru uzyskiwanego przez nie wsparcia społecznego (w postaci emocjonalnej), a także 3) zaprezentowania wpływu niepełnosprawności oraz specyfiki sieci społecznych na subiektywnie odczuwany deficyt wsparcia społecznego przy kontroli zmiennych socjodemograficznych. Analizę oparto na danych pochodzących z ośmiu edycji badań (z lat 2000-2015) realizowanych w ramach Diagnozy Społecznej.

\section{Słowa kluczowe}

niepełnosprawność, nieformalne sieci społeczne, wsparcie społeczne, Diagnoza Społeczna.

\section{WPROWADZENIE}

S zansa na osiągnięcie przez osoby niepełnosprawne pożądanego poziomu zadowolenia z życia jest w sposób immanentny i najczęściej negatywny warunkowana fizycznymi, sensorycznymi lub poznawczymi upośledzeniami. Z jednej strony oddziałują one pod postacią ograniczeń wewnętrznych, wpływających na możliwości motoryczne i percepcyjne jednostki. Z drugiej strony leżą u podstaw ograniczeń zewnętrznych, które formują się jako odpowiedź systemu społecznego na niepełnosprawność. Odpowiedź ta znajduje odzwierciedlenie w rozwiązaniach prawnych, instytucjonalnych, infrastrukturalnych czy kształtujących się w obrębie tego systemu normach i wartościach wpływających na postawy społeczne członków społeczeństwa wobec niepełnosprawności i niepełnosprawnych. W przypadku osób niepełnosprawnych zarówno jedno (zdrowotne), jak i drugie (społeczne) źródło ograniczeń wpływa na poziom ich życia, czyli „jakość warunków egzystencji w sensie stopnia zaspokojenia ważniejszych potrzeb, «urządzenia się», wygody i przyjemności życia. W takim ujęciu jest to synonim najszerzej pojętych warunków życia” (Piasny 1993: 73). Chociaż stan posiadania (dóbr materialnych, środków finansowych, kompetencji, talentów, osiągnięć itp.) jest istotnym czynnikiem wpływającym na poziomu życia, to nie determinuje on jakości życia jako takiego.

W odróżnieniu od poziomu życia, o jakości życia decydują „te wszystkie elementy życia człowieka, które związane są z faktem jego istnienia, bycia kimś i odczuwania różnych stanów emocjonalnych, wypływających np. z faktu posiadania rodziny, kolegów, przyjaciół itp." (Słaby 1990: 8). Dobrostan psychiczny jest zatem tym aspektem 
ludzkiego życia, który nie zależy jedynie od tego, co ktoś ma lub co mu się przydarza, ale od tego, jak o tym myśli lub co w związku z tym czuje (Maddux 2018: 3-4). Jest on zatem doświadczaniem radości, zadowolenia lub pozytywnego samopoczucia, które wiąże się z przekonaniem, że życie jest dobre, znaczące i warte zachodu (Lyubomirsky 2013: 32).

Pomiędzy poziomem i jakością życia zarysowuje się wyraźny podział na materialny standard życia (having) z jednej strony oraz relacje społeczne (loving) i możliwości samorealizacji (being) z drugiej (Allardt 1993). Istotne znaczenie dla oceny tych dwóch ostatnich aspektów ma wsparcie społeczne, uzyskiwane dzięki dostępności osób, które można obdarzyć zaufaniem, na których można polegać i które sprawiają, że jednostka otoczona jest troską i ceni się ją jako osobę. Sieć społeczna pod postacią ról i więzi, które łączą ludzi w dające się zdefiniować ścieżki pokrewieństwa, przyjaźni czy znajomości, jest strukturą dostarczającą takiego wsparcia (McDowell 2006: 152-153). Członkowie nieformalnych sieci społecznych udostępniają zasoby o charakterze emocjonalnym i ułatwiają ich mobilizację. Dla osób niepełnosprawnych, które ze względu na posiadaną dysfunkcję mają ograniczone możliwości pozyskiwania zasobów instrumentalnych pod postacią władzy (pozycji w hierarchii społecznej), statusu ekonomicznego czy prestiżu (zob. Lin 1999: 40), wsparcie udzielane przez najbliższych w formie uznania czy szacunku może pełnić rolę kompensującą wobec tych deficytów lub też stanowić wartość samą w sobie, niezbędną dla podnoszenia jakości życia.

W nawiązaniu do tych spostrzeżeń rodzi się pytanie o to, w jakim stopniu osoby niepełnosprawne w Polsce doświadczają wsparcia społecznego i czy jest ono zależne od charakteru więzi społecznych, w których funkcjonują. Ważne w tym kontekście jest również określenie dynamiki zmian, czyli wskazanie, w jaki sposób charakter sieci społecznych osób niepełnosprawnych (pod względem ich wielkości i gęstości) oraz skala wsparcia społecznego zmieniały się na przestrzeni ostatnich lat. Istotne jest również pytanie o to, czy obecność osób najbliższych jest w stanie skutecznie niwelować oddziaływanie niepełnosprawności (w założeniu negatywne) na ocenę otrzymywanego wsparcia, czy jest ona raczej czynnikiem samoistnie kształtującym tę ocenę. Odpowiedzi na te pytania zostały udzielone dzięki wykorzystaniu danych Diagnozy Społecznej (zob. Diagnoza Społeczna 2015). Podejście ilościowe w badaniu niepełnosprawności oraz zjawisk ją opisujących ma niewątpliwe zalety. Po pierwsze, ogólne i wielowątkowe badania sondażowe, których tematyka nie koncentruje się jedynie na zagadnieniach niepełnosprawności, pozwalają uniknąć efektu „wchodzenia w rolę" niepełnosprawnych uczestników badania i dawania odpowiedzi „zaangażowanych”, udzielanych przez pryzmat doświadczanej niepełnosprawności. Po drugie, badanie dynamiczne, jakim jest Diagnoza Społeczna, umożliwia zaprezentowanie zmian wartości kluczowych zmiennych w czasie. Po trzecie, badanie realizowane na próbie reprezentatywnej pozwala zarówno uogólniać wnioski na całą populację, jak również interpretować wyniki w sposób zrelatywizowany, dzięki możliwości uwzględnienia $\mathrm{w}$ analizie innych kategorii społecznych (tutaj: osób sprawnych), które stanowią dla osób niepełnosprawnych ważna kategorię odniesienia. 
Mówiąc o sieci społecznej danego aktora, mamy na myśli zarówno osoby, z którymi łączą go bezpośrednie relacje (dzięki kontaktom twarzą w twarz), jak również te osoby, które związane są z nim za pośrednictwem innych osób. Na kształt sieci społecznej wpływa jej zasięg, gęstość i złożoność. O zasięgu decyduje różnorodność obecnych w niej aktorów (pod względem charakterystyk społeczno-demograficznych), z którymi dany aktor utrzymuje relacje. Zasięg sieci w tym rozumieniu nie będzie duży, jeśli jednostka utrzymuje relacje tylko z członkami własnej rodziny lub osobami z najbliższego sąsiedztwa. Gęstość sieci społecznej zależy od liczby wzajemnych i silnych powiązań pomiędzy aktorami. Sieć będzie tym gęstsza, im więcej regularnych i bezpośrednich kontaktów łączyć będzie aktorów danej sieci. Z kolei o złożoności sieci społecznej decyduje stopień zróżnicowania typów relacji, które łączą aktora z innymi jej członkami. Jeśli dana osoba, powiązana $\mathrm{z}$ aktorem, będzie pełnić wiele różnych ról społecznych, których odbiorcą jest ten aktor (na przykład będzie jego sąsiadem, a jednocześnie lekarzem rodzinnym czy członkiem tego samego klubu sportowego) to powiązanie takie będzie miało charakter złożony. Jeśli danego aktora będą łączyć z tą osobą jedynie stosunki sąsiedzkie, to będzie to relacja prosta (Burt 1982: 31-32).

Funkcjonując w sieci społecznej, jednostka ma dostęp do dwojakiego rodzaju zasobów. Z jednej strony może wykorzystywać zasoby osobiste, które przyjmują postać dóbr materialnych (kapitał fizyczny czy finansowy) lub symbolicznych (wykształcenie, tytuły naukowe lub honorowe, prestiż społeczny). Zasoby osobiste mogą być w pełni posiadane przez jednostkę (np. kwalifikacje lub pieniądze), dzięki czemu ona sama decyduje, w jaki sposób nimi dysponować. Mogą mieć również charakter „pozycyjny”, niejako przypisany do danej pozycji w strukturze społecznej. Dostęp do nich i szansa ich wykorzystania będą wówczas zależne od tego, czy jednostka zajmuje tę pozycję społeczną. Zasobem w pełni posiadanym przez jednostkę mogą być np. zdolności lingwistyczne, które w dowolny sposób wykorzysta ona w czasie podróży turystycznych. Jednakże określone korzyści, jakie daje nauczanie języków obcych, będą dostępne tylko wówczas, gdy umiejętności te zostaną wykorzystane $\mathrm{w}$ pracy nauczyciela. $\mathrm{Z}$ drugiej strony zasoby społeczne, czyli inaczej kapitał społeczny, to zasoby, do których jednostka uzyskuje dostęp dzięki relacjom społecznym, jakie łączą ją z innymi jednostkami. Tworzą je bogactwo, władza, reputacja oraz sieci społeczne innych aktorów, do których jednostka uzyskuje dostęp dzięki bezpośrednim lub pośrednim więziom społecznym (Lin 2004: 42-43).

Zasoby zawarte w sieciach społecznych zwiększają efektywność działania. Można wskazać kilka mechanizmów odpowiadających za jej wzrost. Po pierwsze, przepływ informacji w sieci prowadzi do obniżenia kosztów transakcyjnych, generowanych przez ryzyko decyzyjne w sytuacji braku adekwatnych informacji. Po drugie, pojawia się możliwość wywierania wpływu przez tych, którzy zajmują w sieci strategiczne pozycje (z większym dostępem do zasobów) i którym inni członkowie sieci przekazują swoje prawa do kontroli w trakcie określonych działań. Po trzecie, członkowie sieci mogą potwierdzać czyjeś referencje lub kwalifikacje poprzez sam fakt istnienia pomiędzy nimi wzajemnych powiązań. Po czwarte, relacje społeczne wzmacniają poczucie tożsamo- 
ści i uznania oraz świadczą o wartości danej jednostki jako członka danej grupy (Lin 2004: 20).

W zależności od charakteru powiązań danego aktora $\mathrm{z}$ innymi jednostkami w sieci społecznej, może on podejmować dwojakiego rodzaju działania. Z jednej strony może bronić posiadanych zasobów, z drugiej strony może starać się uzyskać dostęp do zasobów nowych. Pierwszy typ działań podejmowany jest $\mathrm{z}$ wykorzystaniem więzi silnych, łączących daną jednostką z bliskimi jej osobami (rodziną, przyjaciółmi, znajomymi). Działania te mają naturę ekspresyjną i przynoszą danej jednostce trojakiego rodzaju korzyści: zdrowie fizyczne (przydatne kompetencje fizyczne oraz ochronę przed chorobami czy urazami), zdrowie psychiczne (odporność na stres i utrzymywanie równowagi poznawczej i emocjonalnej) oraz zadowolenie z życia (optymizm i satysfakcję z różnych dziedzin życia - rodziny, małżeństwa, pracy, wspólnoty, itp.). Podjęcie działań drugiego typu ułatwiają więzi słabe, łączące jednostkę z reprezentantami innych sieci społecznych. Dzięki takim powiązaniom uzyskuje ona dostęp do zasobów, którymi nie dysponują członkowie jej własnej sieci. Działania instrumentalne przynoszą aktorom korzyści ekonomiczne, polityczne (pozycja w hierarchii) oraz społeczne w postaci reputacji (Lin 1999: 40).

Dla wielu osób niepełnosprawnych szczególnej wagi nabierają działania o charakterze ekspresyjnym, gdyż dysfunkcja wywołująca niepełnosprawność często ogranicza ich szanse na podjęcie działań instrumentalnych. Z jednej strony dzieje się tak na skutek relatywnie wysokich kosztów, jakie osoby niepełnosprawne muszą ponieść w procesie akumulacji zasobów osobistych (kapitału finansowego, umiejętności czy kwalifikacji), niezbędnych w procesie wymiany ukierunkowanej na pozyskanie nowych zasobów. $\mathrm{Z}$ drugiej strony jest to wynik naturalnych procesów (np. starzenia się), które znacznie zwiększają prawdopodobieństwo niepełnosprawności, a jednocześnie prowadzą do opuszczenia takich obszarów aktywności (edukacyjnego, zawodowego, towarzyskiego), które sprzyjają tworzeniu słabych więzi społecznych, niezbędnych dla prowadzenia skutecznych działań instrumentalnych.

W takich okolicznościach, kiedy dostęp do nowych zasobów staje się utrudniony lub niemożliwy, na znaczeniu zyskują silne więzi społeczne, chroniące przed utratą posiadanych już zasobów. Więzi takie mają charakter symetryczny (odwzajemniony) oraz pozytywny (przychylny) i są warunkowane kilkoma czynnikami: ilością wzajemnie poświęcanego sobie czasu, zaangażowaniem emocjonalnym, poziomem intymności czyli skłonnością do zwierzania się sobie oraz świadczeniem wzajemnej pomocy. W formie tej silne więzi społeczne odgrywają istotną rolę w aktywności o charakterze socjopsychologicznym (Granovetter 1973: 1372-1373).

Najbardziej oczywistym polem dla kształtowania się tego typu więzi jest grono rodzinne, kręgi przyjacielskie czy koleżeńskie. Poprzez relacje z osobami najbliższymi jednostka uzyskuje wsparcie społeczne, które można rozumieć jako „wielowymiarowy konstrukt, który obejmuje pomoc fizyczną i instrumentalną, kształtowanie postaw, dzielenie zasobów i informacji, wsparcie emocjonalne i psychologiczne" (Dunst, Trivette, Cross 1986: 403). Wsparcie takie może przyjmować formę rzeczywistych działań i interwencji (received support), ale również może sprowadzać się do przeświadczenia, że w razie potrzeby zostanie ono udzielone (perceived support) (Wills, Shinar 2000: 87). 
Spośród wszystkich grup pierwotnych, w których funkcjonuje osoba niepełnoprawna, największego znaczenia nabiera rodzina. Udostępnia ona swoim niepełnosprawnym członkom trojakiego rodzaju zasoby. Pierwszą kategorię tworzą zasoby osobiste członków rodziny pod postacią cech osobowościowych, takich jak inteligencja, poczucie humoru czy samoocena, ale również $\mathrm{w}$ formie zdrowia fizycznego najbliższych krewnych. Drugą kategorię stanowią zasoby systemu rodzinnego w postaci spójności i elastyczności. Spójność zapewnia rodzinie przetrwanie, natomiast dzięki elastyczności możliwe jest zaspokajania zróżnicowanych potrzeb członków rodziny i pokonywanie przeszkód, przed którymi oni stają. Do trzeciej kategorii zasobów należą zasoby wspólnotowe, do których rodzina uzyskuje dostęp poprzez fakt przynależności do danej wspólnoty. Członkowie rodziny uzyskują dzięki nim możliwość partycypacji w zróżnicowanych formach aktywności społecznej, ale także w rehabilitacji czy kształtowaniu więzi przyjacielskich i koleżeńskich. Radzenie sobie z niepełnosprawnością, która dotyka członka rodziny, może przybierać różne formy: od eliminowania lub redukcji ilości i intensywności żądań, przed którymi staje osoba niepełnosprawna, poprzez działania mające na celu pozyskanie dostępu do nowych zasobów, zmniejszanie napięcia wywołanego permanentnym stresem powodowanym przez niepełnosprawność, po tworzenie, kształtowanie i ocenę znaczeń związanych z niepełnosprawnością, aby ta stała się bardziej konstruktywna, łatwa do opanowania i akceptowalna (Kosciulek 2007: 84-85).

Dzięki poczuciu istnienia więzi z najbliższymi (sense of bonding), ale przede wszystkim poprzez oparcie ich na wzajemnych zobowiązaniach (sense of binding) strony danej relacji rozumieją oraz podzielają znaczenie odpowiedzialności za dobrostan drugiej strony. To właśnie w takiej sytuacji działania przybierają formę ekspresyjną i pozwalają dzielić się uczuciami, radzić sobie z frustracją, rozumieć problemy drugiej strony oraz potwierdzać własną wartość i umacniać poczucie godności (Lin 1986: 19-20).

Wielu autorów podkreśla istnienie tej przyczynowej zależności - dobrostanu od wsparcia społecznego (House 1981; Leavy 1983; Turner 1983; Cohen, Syme 1985; Vash, Crewe 2004). Pomaga ono na przykład zmniejszyć intensywność reakcji fizjologicznych na stresory, skłaniać ludzi do konstruktywnej oceny trudnych zdarzeń, zachęcać do zachowań profilaktycznych (np. rutynowych ćwiczeń) oraz zniechęcać do działań mogących szkodzić zdrowiu (np. do palenia) (Dunn 2015: 130).

Wsparcie społeczne może przybierać różne formy. Budowanie poczucia własnej wartości na podstawie informacji od osób najbliższych, że jest się nie tylko akceptowanym, ale również cenionym pomimo posiadanych wad, jest wynikiem oddziaływania wsparcia emocjonalnego. Pomocne w rozumieniu problemów i w odnajdowaniu sposobów na ich rozwiązanie jest wsparcie informacyjne. $Z$ kolei wsparcie przynależności pozwala realizować potrzebę afiliacji, a obecność innych ludzi w czasie wspólnego wypoczynku czy rekreacji odwraca uwagę od codziennych zmartwień i problemów. Świadczenie pomocy materialnej, finansowej lub przybierające formę zróżnicowanych usług jest wsparciem instrumentalnym. Z kolei wsparcie walidacyjne jest swoistym sprzężeniem zwrotnym, sygnałem, że negatywne emocje wywoływane koniecznością radzenia sobie z niepełnosprawnością czy też przynależnością do specyficznej kategorii społecznej osób niepełnosprawnych jest czymś naturalnym. Pozwala ono umniejszać znaczenie dysfunkcji, 
akceptować uczucia i budować pozytywny układ odniesienia (Cohen, Wills 1985: 313; Wills, Shinar 2000: 89).

Chociaż oczekiwanie określonej formy wsparcia zależy od złożonego kontekstu krzyżujących się potrzeb, badania pokazują, że wsparcie emocjonalne w porównaniu z innymi formami jest najbardziej skuteczne $\mathrm{w}$ radzeniu sobie $\mathrm{z}$ bodźcami wywołującymi stres (tzw. stresorów). Dotyczy to nawet tych sytuacji, w których oczekiwać należałoby, że bardziej odpowiednie będą inne rodzaje wsparcia (np. przy stresie związanym z sytuacją finansową, ograniczeniach ruchu czy chorobach zagrażających życiu) (Wills, Fegan 2001: 227). Źródłem wsparcia emocjonalnego są osoby najbliższe, dzięki którym kształtuje się samoświadomość i tożsamość osób niepełnosprawnych (Altman 1981). Stałe wsparcie członków rodziny bądź przyjaciół tworzy społeczny (interpersonalny) wymiar, który obok czynników środowiskowych (odpowiednie zasoby wspólnotowe, bezpieczne miejsce zamieszkania, bezpieczeństwo finansowe) i osobistych (zdrowa samoocena, poczucie własnej wartości, umiejętność radzenia sobie z problemami) wpływa na zdolność przywracania równowagi psychospołecznej w obliczu zagrożeń (tutaj: niepełnosprawności) (Craig 2012: 478). Z tego punktu widzenia charakter relacji, jakie łączą osoby niepełnosprawne z bliskimi im osobami, pozostaje kluczowy dla oceny ich jakości życia.

\section{NIEPEŁNOSPRAWNI W SIECIACH SPOŁECZNYCH - ILUSTRACJA EMPIRYCZNA}

W teorii sieci społecznych jednostki tworzące sieć określane są mianem węzłów. Charakter powiązań pomiędzy tymi węzłami można analizować w oparciu o trzy kryteria. Pierwszym z nich jest kryterium normatywne lub formalne. Wskazuje ono liczbę osób, które w stosunku do danej jednostki pełnią społecznie uznawane role: matki, syna, przyjaciela, sąsiada, itp. Drugie kryterium - afektywne - dotyczy osób, które są bliskie danej jednostce i troszczą się o nią. Z kolei kryterium współzależności lub wymiany obejmuje osoby, z którymi jednostka utrzymuje regularne kontakty lub/i wymienia z nimi różne rodzaje zasobów (Fischer 1982). W badaniach Diagnozy Społecznej sieci respondentów charakteryzowane były w oparciu o kryterium drugie i trzecie. W wymiarze afektywnym pytano ich o liczbę osób zaliczanych do grona przyjaciół, a więc osób bliskich im emocjonalnie. Natomiast w wymiarze współzależności proszono o wskazanie liczby osób z najbliższej rodziny, spośród przyjaciół oraz znajomych (z pracy, szkoły, sąsiedztwa), $\mathrm{z}$ którymi badany kontaktował się regularnie, przynajmniej kilka razy $\mathrm{w}$ roku, $\mathrm{w}$ celach towarzyskich i osobistych.

Porównując wielkość kręgów przyjacielskich, w których funkcjonowały osoby niepełnosprawne ${ }^{1}, \mathrm{z}$ kręgami przyjacielskimi osób sprawnych, można dostrzec kilka istotnych zależności. Pomiędzy rokiem 2000 i 2015 średnia liczba osób zaliczanych do grona przyjaciół zarówno przez osoby niepełnosprawne jak i sprawne oscylowała wokół 6 (odpowiednio 6,3 i 6,6 ). O ile jednak w latach $2000-2005$ różnice nie były istotne statystycznie, to w latach następnych (2007-2015) na istotnie większą liczbę przyjaciół wskazywały osoby sprawne (wykres 1 ). 
Wykres 1. Sieci społeczne osób niepełnosprawnych i sprawnych w wymiarze afektywnym (średnia liczba przyjaciół)

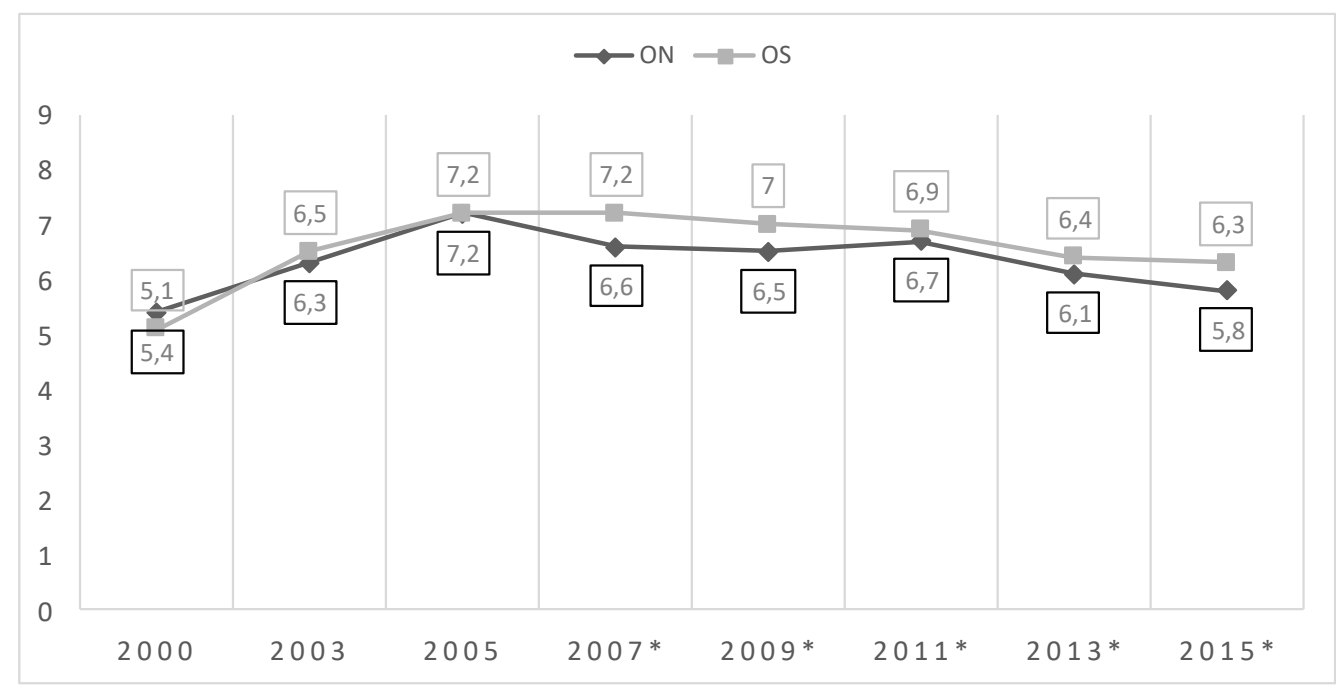

Źródło: opracowanie własne na podstawie Diagnozy Społecznej 2000-2015.

Uwaga: * różnice istotne dla $\mathrm{p}<0,05$ (test Manna-Whitneya).

Osoby niepełnosprawne ustępowały osobom sprawnym również w przypadku liczby regularnych kontaktów utrzymywanych z osobami bliskimi (członkami rodziny, przyjaciółmi i znajomymi). W czterech edycjach badań, w których dokonano takich pomiarów: w roku 2005 oraz w latach 2011-2015, średnia liczna kontaktów osób niepełnosprawnych z członkami rodziny wyniosła 7,6, z przyjaciółmi - 4,4 a ze znajomymi - 5 . Ogólem, osoby niepełnosprawne utrzymywały regularne kontakty średnio z 17 osobami $\mathrm{z}$ tych trzech kręgów. Wartości te były odpowiednio wyższe w przypadku osób sprawnych, a różnice pomiędzy nimi (mierzone testem Manna-Whitneya) istotne statystycznie (poza rokiem 2005, w którym kontakty rodzinne osób niepełnosprawnych i sprawnych były równoliczne). Dla osób sprawnych adekwatne wielkości były równe: dla rodziny - 8,4, dla przyjaciół - 5,7, a dla znajomych - 7,5. Ogólnie, osoby sprawne utrzymywały regularne kontakty średnio z 22 osobami (wykresy 2 i 3). 
Wykres 2. Sieci społeczne osób niepełnosprawnych w wymiarze współzależności (średnia liczba regularnych kontaktów)

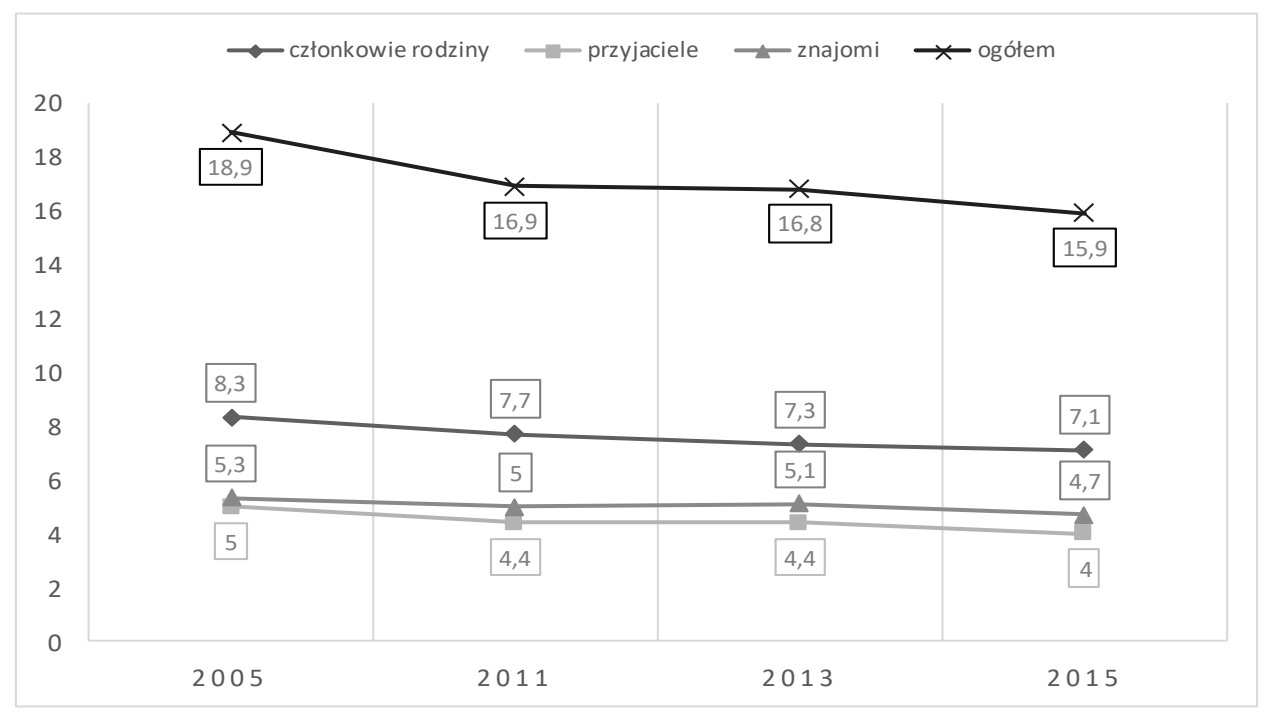

Źródło: opracowanie własne na podstawie Diagnozy Społecznej.

Wykres 3. Sieci społeczne osób sprawnych w wymiarze współzależności (średnia liczba regularnych kontaktów)

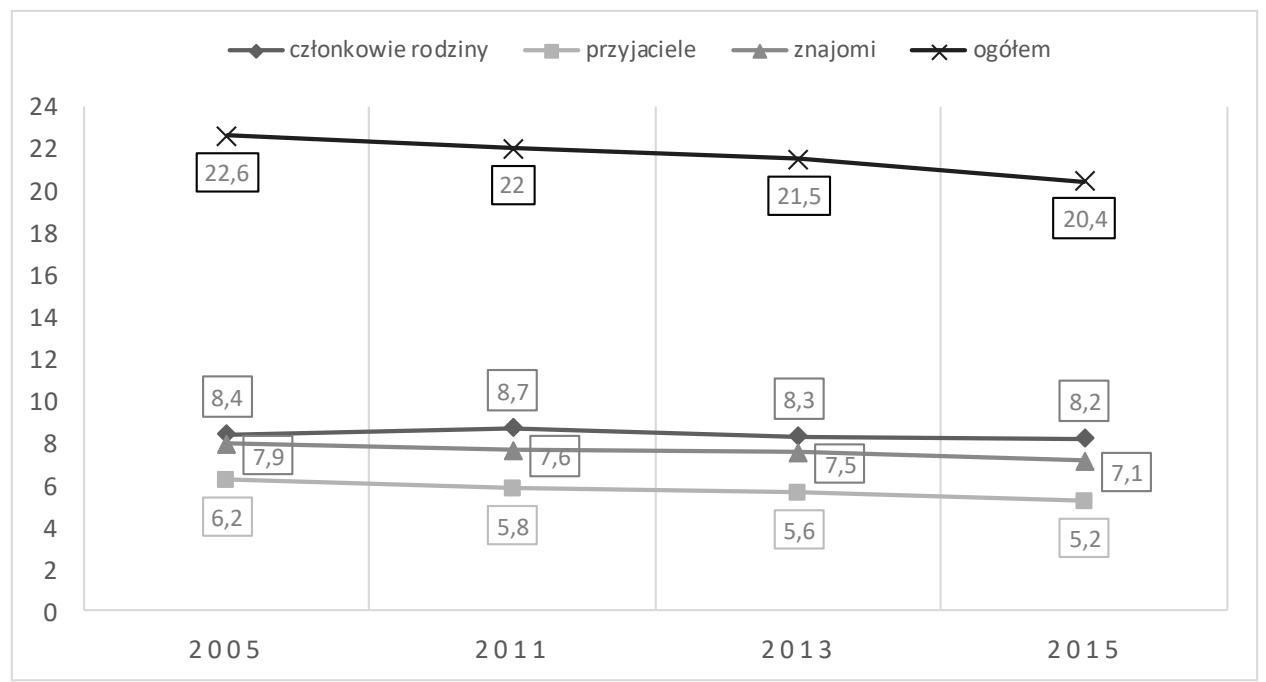

Źródło: opracowanie własne na podstawie Diagnozy Społecznej. 
Odnosząc się do zaprezentowanych wartości, można wskazać charakterystyczne wzory zależności. Po pierwsze, sieci społeczne osób niepełnosprawnych są mniejsze zarówno w wymiarze afektywnym, jak i w wymiarze współzależności w porównaniu z sieciami społecznymi osób sprawnych. Po drugie, zarówno w przypadku jednej, jak i drugiej porównywanej kategorii, sieci społeczne na obu wymiarach zmniejszały się w ostatnich latach badań.

Od wielkości sieci społecznej może, choć nie musi, zależeć szansa na uzyskanie wsparcia, gdyż zasoby sieci społecznej w wymiarze strukturalnym (liczba kontaktów) nie muszą pokrywać się z zasobami sieci w wymiarze funkcjonalnym (jakość kontaktów). Tak więc sama wielkość sieci z pewnością sprzyja, ale nie determinuje tego, czy jednostka uzyska oczekiwane wsparcie czy też nie. Należy jednak podkreślić, że zarówno wsparcie funkcjonalne, jak i strukturalne jest pozytywnie powiązane $\mathrm{z}$ kondycją zdrowotną jednostek (Wills, Fegan 2001: 210; Taylor 2007: 145).

Różnice w otrzymywanym wsparciu pomiędzy osobami niepełnosprawnymi i sprawnymi odzwierciedlają dane. Jednym z pytań wykorzystanych w Diagnozie Społecznej do pomiaru wsparcia społecznego ( $w$ jego emocjonalnej postaci) było pytanie o poczucie osamotnienia wbrew własnej woli. Biorąc pod uwagę wszystkie edycje badań, do samotności przyznawała się średnio co trzecia osoba niepełnosprawna (29,4\%), gdy wśród sprawnych średni odsetek osób samotnych wyniósł 19,1\%. We wszystkich ośmiu edycjach badań różnice liczbowe pomiędzy obiema kategoriami były istotne statystycznie (wykres 4).

Wykres 4. Osoby niepełnosprawne i sprawne z poczuciem osamotnienia [\%]

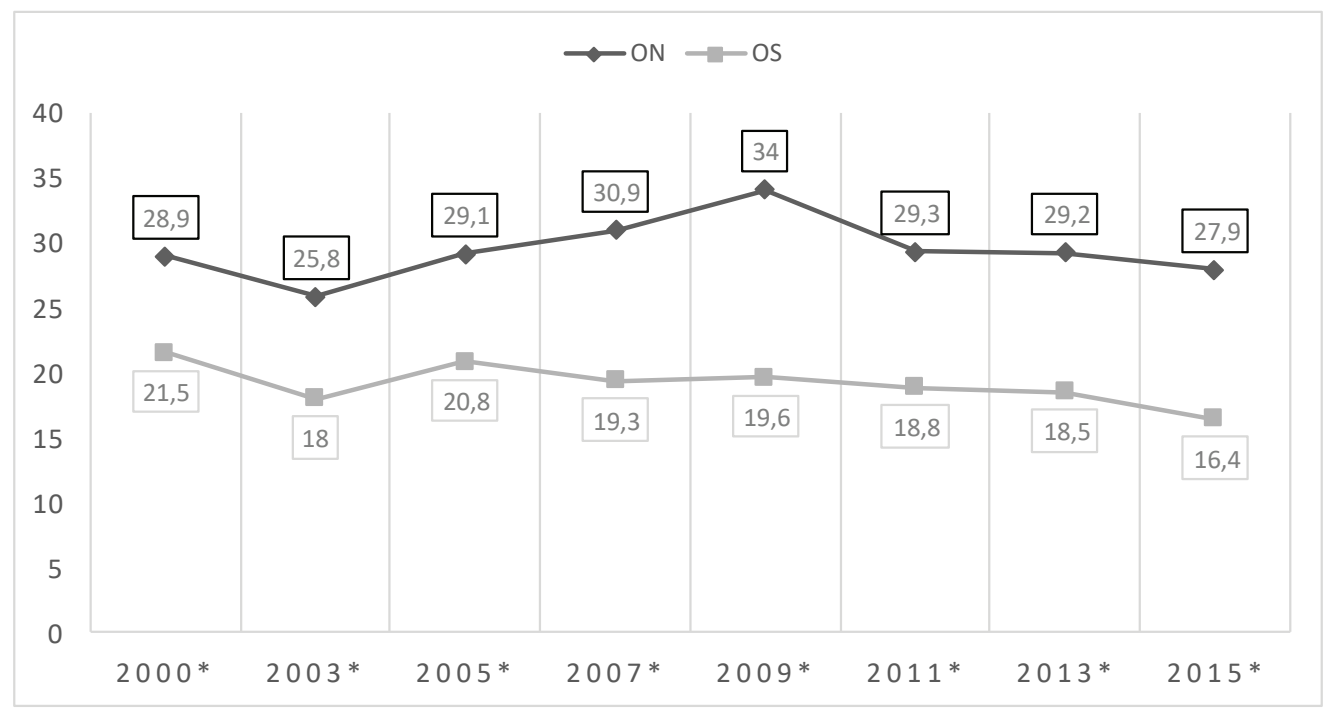

Źródło: opracowanie własne na podstawie Diagnozy Społecznej.

Uwaga: * różnice istotne dla p $<0,05$ (phi). 
Drugim pytaniem, będącym wskaźnikiem otrzymywanego wsparcia emocjonalnego, było pytanie o poczucie bycia kochanym i darzonym zaufaniem. Do deficytu w tym wymiarze przyznawała się średnio co dziewiąta osoba niepełnosprawna $(11,8 \%)$ i co dwunasta osoba sprawna $(8,4 \%)$. Podobnie jak w przypadku poczucia osamotnienia, także i tutaj, w każdym roku pomiaru, osoby niepełnosprawne różniły się istotnie od osób sprawnych (wykres 5).

Wykres 5. Osoby niepełnosprawne i sprawne nieobdarowywane miłością i zaufaniem [\%]

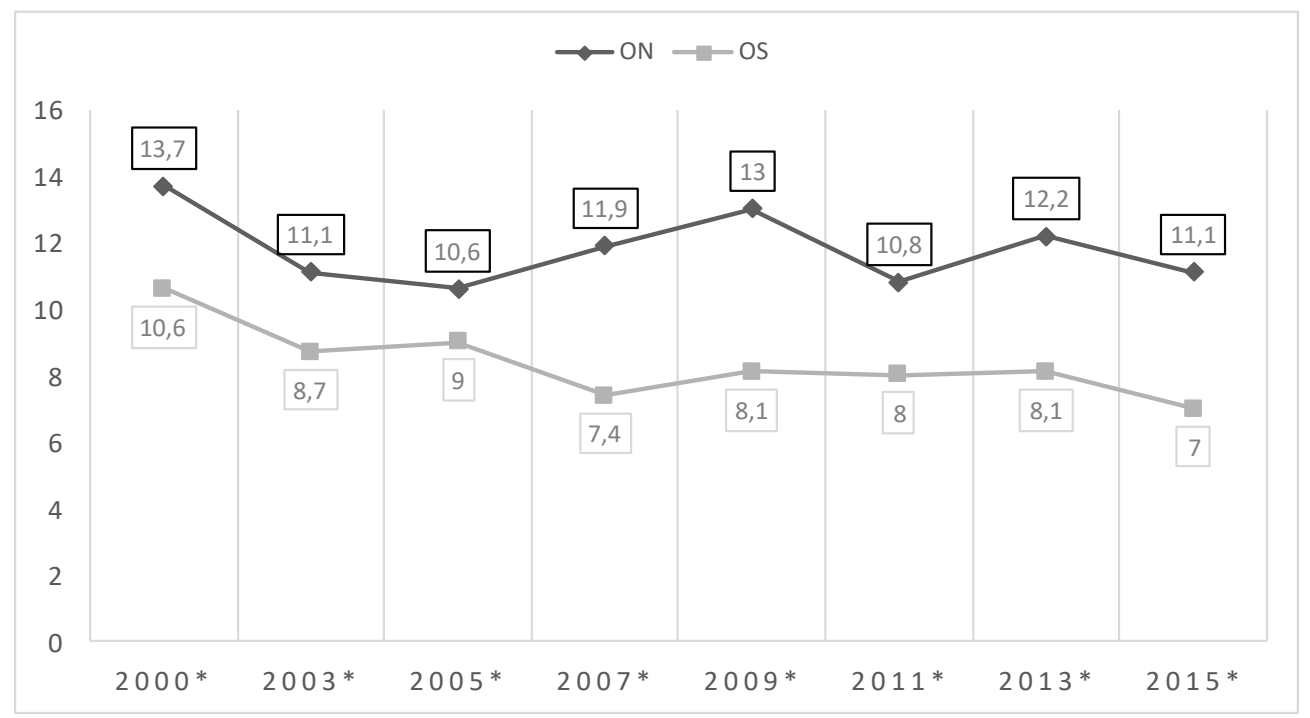

Źródło: opracowanie własne na podstawie Diagnozy Społecznej.

Uwaga: ${ }^{\star}$ różnice istotne dla $\mathrm{p}<0,05$ (phi).

Obserwowane różnice, które wypadają na niekorzyść osób niepełnosprawnych, można interpretować w odniesieniu do samej niepełnosprawności (jako ich przyczyny), ale także do innych cech demograficznych i społecznych. Należy bowiem pamiętać, że osoby niepełnosprawne tworzą specyficzną kategorię społeczną o charakterystycznych cechach. Są to na ogół osoby starsze, gorzej wykształcone, o relatywnie niskim statusie ekonomicznym, bierne zawodowo i edukacyjnie (Masłyk 2019). Tak więc na potencjał budowania sieci społecznych przez osoby niepełnosprawne może wpływać ich dysfunkcja, ale równie prawdopodobne jest, że wpływ ten będzie zapośredniczony oddziaływaniem innych zmiennych, powiązanych z niepełnosprawnością.

Aby odpowiedzieć na pytanie, czy niepełnosprawność sama w sobie jest istotnym predyktorem poczucia braku wsparcia społecznego, posłużono się modelem regresji logistycznej. W modelu tym zmienną zależną była zmienna binarna, dla której wartością 1 
oznaczono osoby wskazujące poczucie osamotnienia przy jednoczesnym braku miłości i zaufania, natomiast wartością 0 te osoby, które przynajmniej na jednym z tych wymiarów nie odczuwały deficytu. Zmiennymi niezależnymi wprowadzonymi do modelu były: wielkość sieci społecznych (mierzona liczbą przyjaciół), gęstość sieci społecznych (mierzona liczbą regularnych kontaktów z bliskimi) ${ }^{2}$ oraz niepełnosprawność z uwzględnieniem jej różnych stopni (znacznego, umiarkowanego, lekkiego i niepełnosprawności bez orzeczenia). W modelu znalazły się również zmienne kontrolne, takie jak płeć, wiek, wykształcenie, dochód netto na rękę, miejsce zamieszkania, status społeczno-zawodowy i stan cywilny, a więc zmienne, które silnie różnicują kategorie osób sprawnych i niepełnosprawnych. Zbiór tych zmiennych uzupełniono również zmienną odróżniającą uczestników nabożeństw religijnych i tych, którzy w nich nie uczestniczą. W wielu badaniach wskazuje się, że religia ułatwia radzenie sobie ze stresem (Pargament i in. 1999; Oman, Thoresen 2002), między innymi w oparciu o wewnątrzgrupową tożsamość (Ysseldyk, Matheson, Anisan 2010), która w rezultacie daje poczucie wsparcia społecznego (Merino 2014). Wyniki przeprowadzonej analizy zaprezentowano w tabeli 1.

Tabela 1. Związek pomiędzy charakterem sieci społecznej, cechami socjodemograficznymi i niepełnosprawnością a poczuciem wsparcia społecznego: wyniki estymacji modelu regresji logistycznej

\begin{tabular}{|l|l|l|}
\hline \multicolumn{2}{|c|}{ Zmienne } & \multicolumn{1}{c|}{$\begin{array}{c}\text { Odczuwany } \\
\text { brak wsparcia }\end{array}$} \\
\cline { 3 - 3 } & Exp(B) \\
\hline Płeć (ref: kobieta) & mężczyzna & 0,925 \\
\hline \multirow{4}{*}{ Wiek (ref: 16-24 lata) } & $25-34$ lat & $1,591^{*}$ \\
\cline { 2 - 3 } & $35-44$ lat & $2,688^{*}$ \\
\cline { 2 - 3 } & $45-55$ lat & $2,825^{\star}$ \\
\cline { 2 - 3 } & $56-65$ lat & $2,422^{*}$ \\
\cline { 2 - 3 } & powyżej 65 lat & $2,134^{*}$ \\
\hline \multirow{3}{*}{$\begin{array}{l}\text { Wykształcenie } \\
\text { (ref: nie wyższe niż podstawowe) }\end{array}$} & gimnazjum/zawodowe & 0,937 \\
\cline { 2 - 3 } & średnie & 0,922 \\
\cline { 2 - 3 } & policealne/wyższe & 0,902 \\
\hline \multirow{3}{*}{$\begin{array}{l}\text { Dochód } \\
\text { (ref: poniżej 1 kwartyla) }\end{array}$} & $1-2$ kwartyle & 0,896 \\
\cline { 2 - 3 } & $2-3$ kwartyle & $0,767^{*}$ \\
\cline { 2 - 3 } & powyżej 3 kwartyla & $0,653^{*}$ \\
\hline
\end{tabular}




\begin{tabular}{|c|c|c|}
\hline \multirow{5}{*}{$\begin{array}{l}\text { Miejsce zamieszkania } \\
\text { (ref: wieś) }\end{array}$} & miasta powyżej 500 tys. & 1,100 \\
\hline & miasta $200-500$ tys. & $1,260^{*}$ \\
\hline & miasta $100-200$ tys. & 0,980 \\
\hline & miasta $20-100$ tys. & 1,053 \\
\hline & miasta poniżej 20 tys. & 1,018 \\
\hline \multirow{8}{*}{$\begin{array}{l}\text { Status społeczno-zawodowy } \\
\text { (ref: pracownicy sektora } \\
\text { państwowego) }\end{array}$} & pracownicy sektora prywatnego & 0,874 \\
\hline & prywatni przedsiębiorcy & $0,707^{\star}$ \\
\hline & rolnicy & 1,007 \\
\hline & renciści & 1,004 \\
\hline & emeryci & 0,977 \\
\hline & uczniowie i studenci & 0,777 \\
\hline & bezrobotni & 1,149 \\
\hline & inni bierni zawodowo & 1,023 \\
\hline \multirow{5}{*}{$\begin{array}{l}\text { Stan cywilny } \\
\text { (ref: panna/kawaler) }\end{array}$} & żonaty/zamężna & $0,362^{*}$ \\
\hline & wdowiec/wdowa & $1,233^{*}$ \\
\hline & rozwiedziony/rozwiedziona & 1,070 \\
\hline & separacja prawna & 0,954 \\
\hline & separacja faktyczna & $1,776^{*}$ \\
\hline $\begin{array}{l}\text { Uczestnictwo w nabożeństwach } \\
\text { (ref. uczestniczący) }\end{array}$ & nieuczestniczący & 1,539 \\
\hline \multirow{4}{*}{$\begin{array}{l}\text { Stopień niepełnosprawności } \\
\text { (ref. sprawni) }\end{array}$} & znaczny & 1,193 \\
\hline & umiarkowany & $1,442^{*}$ \\
\hline & lekki & $1,451^{*}$ \\
\hline & bez orzeczenia & $1,777^{\star}$ \\
\hline \multicolumn{2}{|l|}{ Liczba przyjaciół } & $0,955^{\star}$ \\
\hline \multicolumn{2}{|c|}{ Liczba regularnych kontaktów (rodzina, przyjaciele, znajomi) } & $0,994^{*}$ \\
\hline \multicolumn{2}{|c|}{$\mathrm{R}^{2}$ Nagelkerkego } & 0,133 \\
\hline
\end{tabular}

Źródło: opracowanie własne na podstawie Diagnozy Społecznej 2000-2015.

Uwaga: ${ }^{*}$ dla $\mathrm{p}<0,01$.

Iloraz szans $\operatorname{Exp}(B)$ informuje o tym, jaka jest szansa zdarzenia (tutaj: doświadczania wsparcia społecznego) dla danej wartości (kategorii) zmiennej niezależnej (i przy kontroli wpływu pozostałych zmiennych) w porównaniu z wartością (kategorią) referencyjną tej zmiennej. 
W przypadku zmiennych socjodemograficznych, prawdopodobieństwo odczuwania deficytu wsparcia społecznego $\mathrm{w}$ jego emocjonalnej formie zależało przede wszystkim od wieku, dochodu oraz stanu cywilnego. W porównaniu z kategorią referencyjną wieku (1624 lata), reprezentanci każdej innej kategorii wiekowej charakteryzowali się istotnie wyższą szansą poczucia osamotnienia i braku miłości bądź zaufania. Wysokość dochodu powyżej mediany obliczonej dla ogółu respondentów istotnie zmniejszała prawdopodobieństwo poczucia braku wsparcia emocjonalnego. Dla osób o zarobkach poniżej tej wartości szansa ta rosła. W odniesieniu do stanu cywilnego, dla którego kategorią referencyjną były panny lub kawalerowie, istotnie niższą szansą na doświadczanie braku wsparcia emocjonalnego charakteryzowały się osoby pozostające w związkach małżeńskich. Z drugiej strony, istotnie wyższym prawdopodobieństwem braku wsparcia odznaczały się osoby owdowiałe lub pozostające $\mathrm{w}$ separacji faktycznej. Miejsce zamieszkania różnicowało istotnie tylko jedną kategorię względem kategorii referencyjnej (wsi). W porównaniu z nią mieszkańcy miast 200-500 tysięcznych z istotnie wyższym prawdopodobieństwem uskarżali się na brak wsparcia emocjonalnego. W odniesieniu do statusu społeczno-zawodowego, istotnie niższą szansą na brak wsparcia w porównaniu z kategorią referencyjną (pracownicy sektora publicznego) charakteryzowali się prywatni przedsiębiorcy. W obrębie innych zmiennych socjodemograficznych - płci i wykształcenia, jak również zmiennej odnoszącej się do uczestnictwa w nabożeństwach religijnych, nie odnotowano istotnych różnic.

W zbiorze zmiennych niezależnych znalazły się cechy opisujące charakter sieci społecznych (ich wielkość i gęstość) oraz stopień niepełnosprawności. Mając na uwadze fakt, że osoby niepełnosprawne $\mathrm{w}$ porównaniu $\mathrm{z}$ osobami sprawnymi funkcjonują $\mathrm{w}$ relatywnie mniejszych, nieformalnych sieciach społecznych, które jednocześnie odznaczają się mniejszą gęstością, szukano odpowiedzi na pytanie, czy kształt sieci społecznych warunkowany tymi dwiema cechami wpływa na odczuwane wsparcie w wymiarze emocjonalnym. $\mathrm{Z}$ drugiej strony próbowano ustalić, czy niepełnosprawność sama w sobie, przy wyłączeniu oddziaływania szeregu zmiennych socjodemograficznych, jest istotnym predyktorem poczucia osamotnienia przy jednoczesnym odczuwaniu braku miłości i zaufania. Przeprowadzona analiza wykazała, że wszystkie trzy zmienne były istotnymi predyktorami deficytów wsparcia. Z jednej strony, wraz ze wzrostem liczby przyjaciół oraz częstotliwości regularnych kontaktów z osobami bliskimi zmniejszało się prawdopodobieństwo przynależności do kategorii osób samotnych, doświadczających braku miłości i zaufania. $Z$ drugiej strony, niezależnie od konfiguracji wartości innych zmiennych, niepełnosprawność pogłębiała ten brak. Nie dotyczyło to jednak wszystkich kategorii niepełnosprawności. W porównaniu z kategorią referencyjną, czyli osobami sprawnymi, istotnie wyższym prawdopodobieństwem poczucia braku wsparcia odznaczały się osoby z umiarkowaną, lekką i nieorzeczoną niepełnosprawnością. Pod tym względem osoby z niepełnosprawnością znaczną nie różniły się od osób sprawnych. Ten ciekawy wynik można tłumaczyć nieodzowną potrzebą obecności osób bliskich, bez których radzenie sobie w codziennej aktywności ograniczanej głęboką dysfunkcją byłoby w przypadku takich osób znacznie utrudnione lub niemożliwe do zrealizowania. Natomiast niepełnosprawność umiarkowana, lekka lub nieorzeczoną nie wymusza takiej konieczności i stąd bliskość osób ma charakter „dobrowolny”, w mniejszym stopniu warunkowany poczuciem obowiązku. 


\section{ZAKOŃCZENIE}

Pomoc udzielana osobom niepełnosprawnym czy ich samodzielne radzenie sobie z niepełnosprawnością, które polega na dążeniu do zachowania lub przywrócenia pełnego dobrostanu, wiązane są najczęściej z pokonywaniem barier wywołanych przez dysfunkcję. Źródeł tych barier szuka się bądź w kondycji zdrowotnej jednostki, bądź w środowisku społecznym, w którym jednostka ta funkcjonuje. Istotne w trakcie opracowywania scenariuszy pomocy niwelującej ograniczenia jest to, aby nie przeoczyć innych, uniwersalnych potrzeb ludzkich, których zaspokojenia potrzebuje każdy, nie tylko niepełnosprawny członek społeczeństwa. Wiele lat temu na fakt ten zwracała uwagę Światowa Organizacja Zdrowia, definiując zdrowie jako „stan pełnego fizycznego, umysłowego i społecznego dobrostanu, a nie tylko brak choroby czy niemocy, zniedołężnienia (infirmity)" (WHO 1946: 1). W tym rozumieniu zdrowie warunkowane jest nie tylko kondycją samego organizmu, ale również szeregiem innych czynników, bezpośrednio z nim niezwiązanych. Można zatem mówić tutaj o złożonym „modelu ekologicznym”, który wiąże w sobie wiele kategorii zdrowotnych determinant. Tworzą je: 1) czynniki intrapersonalne (wiedza, postawy, zachowania, samoocena, umiejętności), 2) procesy interpersonalne i grupy pierwotne (formalne i nieformalne sieci społeczne i system wsparcia społecznego tworzone przez rodzinę, współpracowników i przyjaciól, 3) czynniki instytucjonalne (instytucje społeczne o charakterze organizacyjnym $\mathrm{z}$ formalnymi i nieformalnymi zasadami i przepisami dotyczącymi działania), 4) czynniki społecznościowe (relacje między organizacjami, instytucjami i sieciami nieformalnymi zachodzące w określonych granicach), 5) polityka publiczna (lokalne i państwowe prawa i polityki) (McLeroy i in. 1988: 355).

Sieci społeczne i wsparcie społeczne są zatem nieodzownymi czynnikami wpływającymi na jakość życia jednostek. Ich kształtowanie w przypadku osób niepełnosprawnych napotyka trudności. Wywołuje je sama dysfunkcja, często ograniczająca szanse budowania relacji społecznych, lecz są również pochodną innych cech socjodemograficznych, które współistnieją razem z niepełnosprawnością. Relatywnie wyższy średni wiek i powodowane nim ograniczenia aktywności edukacyjnej czy zawodowej, ale także większe trudności we wchodzeniu w związki o charakterze emocjonalnym powodują, że sieci społeczne osób niepełnosprawnych są relatywnie mniejsze w porównaniu z sieciami osób sprawnych. Dotyczy to zarówno wymiaru afektywnego, czyli liczby osób pozostających w relacjach przyjacielskich, jak również wymiaru współzależności, charakteryzowanego liczbą regularnych kontaktów z bliskimi. Ograniczenia te zmniejszają szansę na mobilizację zasobów emocjonalnych, odpowiedzialnych za utrzymanie zdrowia fizycznego, ale nade wszystko, do jakże istotnego dla osób niepełnosprawnych zachowania zdrowia psychicznego czy zadowolenia z życia.

Jak pokazały wyniki analizy problem dostępu do zasobów emocjonalnych zawartych w sieciach społecznych pogłębiają także inne czynniki. Sieci społeczne osób niepełnosprawnych są nie tylko relatywnie małe (w sensie wielkości i gęstości), ale również zmniejszają się w czasie. Przyczyn tego faktu należy poszukiwać w tendencji do przekształcania się wzorów życia społecznego we współczesnych społeczeństwach: w zmianach struktury rodziny, atomizacji życia społecznego, w mniejszej trwałości 
związków emocjonalnych (w tym małżeńskich). Innym czynnikiem ograniczającym dostęp do wsparcia społecznego jest niepełnosprawność sama w sobie. Wprawdzie zgodnie $\mathrm{z}$ wynikami analizy niepełnosprawność doświadczana $\mathrm{w}$ stopniu znacznym nie wpływa (przy kontroli innych zmiennych) na subiektywne odczuwanie wsparcia, ale dla pozostałych osób niepełnosprawnych ma ona istotne znaczenie. Życie w świecie determinowanym przez dysfunkcję, która nie jest na tyle głęboka, aby warunkowała konieczność stałej obecności i opieki ze strony innych osób, może wywoływać poczucie samotności czy odrzucenia. $\mathrm{W}$ tym aspekcie osobistych doświadczeń zrozumienie niepełnosprawności jest niezwykle trudne. $\mathrm{O}$ wiele przystępniejszą wydaje się próba poznania niepełnosprawności w perspektywie relacji, które osoby niepełnosprawne tworzą z bliskim i które to relacje stanowią niezbędne źródło wsparcia pomocne w uzyskaniu satysfakcjonującej jakości życia.

\section{BIBLIOGRAFIA}

Allardt, Erik (1993). Having, Loving, Being: An Alternative to the Swedish Model of Welfare Research. W: Martha Nussbaum, Amartya Sen (red.). The Quality of Life. Oxford: Clarendon Press, s. 88-94.

Altman, Barbara M. (1981). Studies of Attitudes Toward the Handicapped: The Need for New Direction. „Social Problems”, 28, s. 321-337.

Burt, Ronald S. (1982). Toward Structural Theory of Action. Network Models of Social Structure, Perception, and Action. New York: Academic Press.

Cohen, Sheldon, Syme Leonard S. (red.) (1985). Social Support and Health. San Francisco: Academic Press.

Cohen, Sheldon, Wills, Thomas A. (1985). Stress, Social Support, and the Buffering Hypothesis. „Psychological Bulletin”, 98, s. 310-357.

Craig, Ashley (2012). Resilience in People with Physical Disabilities. W: Paul Kennedy (red.). The Oxford Handbook of Rehabilitation Psychology. New York: Oxford University Press, s. 474-491.

Diagnoza Społeczna (2015). Zintegrowana baza danych. www.diagnoza.com (dostęp: 13.03.2017).

Dunn, Dana S. (2015). The Social Psychology of Disability. New York: Oxford University Press.

Dunst, Carl J., Trivette, Carol, Cross, Arthur H. (1986). Mediating Influences of Social Support: Personal, Family and Child Outcomes. „American Journal of Mental Deficiency", 90, s. 403-417.

Fischer, Claude S. (1982). To Dwell among Friends: Personal Networks in Town and City. Chicago: University of Chicago Press.

Granovetter, Mark (1973). The Strength of Weak Ties. „American Journal of Sociology”, 78, s. $1360-1380$. 
House, James S. (1981). Work, stress and social support. Reading Mass: Addison-Wesley.

Kosciulek, John F. (2007). The Social Context of Coping. W: Erin Martz, Hanoch Livneh (red.). Coping with Chronic Illness and Disability. Theoretical, Empirical, and Clinical Aspects. New York: Springer, s. 73-88.

Lin, Nan (1986). Conceptualizing Social Support. W: Nan Lin, Alfred Dean, Walter M. Ensel (red.). Social Support, Life Events, and Depression. Orlando: ACADEMIC PRESS, INC., s. 17-30.

Lin, Nan (1999). Building a Network Theory of Social Capital. „CONNECTIONS”, 22, s. $28-51$.

Lin, Nan (2004). Social Capital. A Theory of Social Structure and Action. Cambridge: Cambridge University Press.

Leavy, Richard L. (1983). Social support and psychological disorder: A review. „Journal of Community Psychology", 11, s. 3-21.

Lyubomirsky, Sonja (2013). The myths of happiness: What should make you happy, but doesn't, what shouldn't make you happy, but does. New York: Penguin Press.

Maddux, James E. (2018). Subjective Well-Being and Life Satisfaction. An Introduction to Conceptions, Theories, and Measures. W: James E. Maddux (red.). Subjective Well-Being and Life Satisfaction. New York: Routledge, s. 3-31.

Masłyk, Tomasz (2019). Po pierwsze człowiek. Kapitał społeczny osób niepełnosprawnych $w$ Polsce. Warszawa: Wydawnictwo Naukowe Scholar.

McDowell, Ian (2006). Measuring Health. A Guide to Rating Scales and Questionnaires. New York: Oxford University Press.

McLeroy, Keneth R., Bibeau, Daniel L., Steckler, Adrienne, Glanz, Karen (1988). An Ecological Perspective on Health Promotion Programs. „Health Education Quarterly”, 15, s. 351-377.

Merino, Stephen M. (2014). Social Support and the Religious Dimensions of Close Ties. "Journal for the Scientific Study of Religion", 53, s. 595-612.

Oman, Doug, Thoresen, Carl E. (2002), 'Does Religion Cause Health?': Differing Interpretations and Diverse Meanings. „Journal of Health Psychology”, 7, s. 365-380.

Pargament, Kenneth I., Cole, Brenda, Vandercreek, Larry, Belavich, Timothy, Brant, Curtis, Perez, Lisa (1999). The Vigil: Religion and the Search for Control in the Hospital Waiting Room. „Journal of Health Psychology”, 4, s. 327-341.

Piasny, Janusz (1993). Poziom i jakość życia ludności oraz źródła i mierniki ich określania. „Ruch Prawniczy, Ekonomiczny i Socjologiczny”, 55, s. 73-92.

Słaby, Teresa (1990). Poziom życia, jakość życia. „Wiadomości Statystyczne”, 6, s. 8-10.

Stark, Rodnay (1982). Religion and Delinquency: the Ecology of a "Lost” Relationship. „Journal of Research in Crime and Delinquency", 19, s. 4-24.

Taylor, Shelley E. (2007). Social Support. W: Howard. S. Friedman, Roxane C. Silver (red.). Foundations of Health Psychology. New York: Oxford University Press, s. 145-171. 
Turner, Jay R. (1983). Direct, indirect and moderating effects of social support upon psychological distress and associated conditions. W: Howard. B. Kaplan (red.). Psychosocial stress. Trends in theory and research. New York: Academic Press, s. 105-155.

Vash, Carolyn L., Crewe, Nancy M. (2004). Psychology of disability (2nd ed.). New York: Springer Publishing Company.

WHO. 1946. Constitution of the World Health Organization. http://apps.who.int/gb/bd/ PDF/bd47/EN/constitution-en.pdf (dostęp: 27.04.2017).

Wills, Thomas A., Fegan, Marnie F. (2001). Social Networks and Social Support. W: Andrew Baum, Tracey A. Revenson, Jerome E. Singer (red.). Handbook of Health Psychology. Mahwah: Lawrence Erlbaum Associates, Inc, s. 209-234.

Wills, Thomas A., Shinar, Ori (2000). Measuring Perceived and Received Social Support. W: Sheldon Cohen, Lynn G. Underwood, Benjamin H. Gottlieb (red.). Social Support Measurement and Intervention. A Guide for Health and Social Scientists. New York: Oxford University Press, s. 86-135.

Ysseldyk, Renate, Matheson, Kimberly, Anisan, Hymie (2010). Religiosity as Identity: Toward an Understanding of Religion From a Social Identity Perspective. "Personality and Social Psychology Review", 14, s. 60-71.

\section{PRZYPISY}

1 W badaniach Diagnozy Społecznej respondenci kwalifikowani byli do kategorii osób niepełnosprawnych na podstawie dwóch kryteriów: prawnego (posiadanie orzeczenia komisji lekarskiej o niepełnosprawności, z podziałem na stopień znaczny, umiarkowany i lekki) i biologicznego (oświadczenie o kalectwie lub przewlekłej chorobie, ograniczających możliwość wykonywania podstawowych czynności życiowych).

2 Zmienną tę wprowadzono w postaci indeksu o wartościach będących sumą kontaktów z członkami rodziny, przyjaciółmi i znajomymi. Powiązanie tych trzech wielkości było możliwe dzięki satysfakcjonująco silnym korelacjom pomiędzy tymi trzema pojedynczymi zmiennymi, zarówno w przypadku osób niepełnosprawnych, jak i sprawnych (wartość alfa Cronbacha $>0,65$ ). 